\title{
Height, Weight and Body Mass Index Percentiles of Children Aged 6-14 Years Living at Moderate Altitudes
}

\author{
Ismail Malkoç1, Mümtaz M. Mazıcıoğlu2, Behzat Özkan3, \\ Meda Kondolot4, Selim Kurtoğlu4, Hakkı Yeşilyurt5 \\ ${ }^{1}$ Ataturk University Faculty of Medicine, Department of Anatomy, Erzurum, Turkey \\ 2Erciyes University Faculty of Medicine, Department of Family Medicine, Kayseri, Turkey \\ 3/stanbul Medeniyet University Faculty of Medicine, Department of Pediatric Endocrinology, Istanbul, Turkey \\ ${ }^{4}$ Erciyes University Faculty of Medicine, Department of Pediatric Endocrinology, Kayseri, Turkey \\ 5 Undersecretary of Ministry of Health, Department of Anatomy, Ankara, Turkey
}

\begin{abstract}
Objective: Individuals living at high altitudes are reported to have lower stature and also a smaller chest size in relation to their stature. Altituderelated hypobaric hypoxia is considered to be the major cause of these alterations in growth, but adverse socioeconomic and/or other environmental conditions may also have a role in poor growth performance. This study was undertaken to provide growth data on children and adolescents living in a moderate-altitude area in Turkey.

Methods: The dataset of an anthropometric study conducted among a population living in a city at an altitude of 2000 meters was analyzed. A total of 1638 children and adolescents (871 males and 767 females) aged between 6 and 14 years were included in this study. The LMS method was used in the analysis and percentile values corresponding to the $3^{\text {rd }}, 5^{\text {th }}, 10^{\text {th }}, 15^{\text {th }}, 25^{\text {th }}$, $50^{\text {th }}, 75^{\text {th }}, 85^{\text {th }}, 90^{\text {th }}, 95^{\text {th }}$ and $97^{\text {th }}$ percentiles for height, weight and body mass index (BMI) were estimated. The results were compared with the measurements of children and adolescents living in areas of lower altitude in Turkey.

Results: Starting at ages 0-10 years, height, weight and BMI values of children and adolescents of both genders living at an altitude of 2000 meters were noticeably lower than those reported for their counterparts living in areas of lower altitude in Turkey.

Conclusions: The higher values for height, weight and BMI in children living in low-altitude areas can be attributed to altitude effect, but socioeconomic and microclimate effects cannot be discarded and further studies are needed. Key words: Weight, height, body mass index, adolescents, mid altitude, percentiles
\end{abstract}

Conflict of interest: None declared Received: 08.12.2011

Accepted: 14.01 .2012

\section{Introduction}

\section{Implications and Contribution}

Children living in different locations or under certain environmental conditions may need specific screening or followup criteria. Data on growth performance of children living in highaltitude areas will provide useful information for both screening and research purposes.

Growth and development are complex physiological processes controlled or directed by several hormonal, environmental and genetic factors (1). Altitude is one of the environmental factors which may interfere with growth and development primarily by exposure to hypoxia $(2,3)$. High altitude is defined as the level at which oxygenated hemoglobin concentration is lower than $90 \%$ and corresponds to altitudes of at least 2500 meters. Acute and chronic exposure to altituderelated hypoxia may lead to several permanent multisystemic problems $(3,4)$.

Exposure to altitudes between 1500 and 2500 meters (representing moderate altitude levels) has also been reported to cause various undesirable effects. $15-25 \%$ of individuals visiting these areas experience acute mountain sickness (5). Some other high altitude-related problems may be experienced at moderate altitudes as well (6). 
The primary consequence of altitude-related alterations in growth is a decrease in linear growth and a smaller chest size relative to stature. However, the effects of the microclimate as well as that of socio-demographic variables are also pointed out as causes of growth problems in children living at high altitudes $(7,8)$.

While the effects of ethnic, socioeconomic and/or nutritional factors are well-documented, studies which analyze the effect of climate as a primary parameter interfering with growth are scarce $(4,5,6)$. Our rationale for conducting this study was to produce weight, height and body mass index (BMI) percentile values in children and adolescents living at moderate altitude levels and to compare these values with the results of other growth studies in Turkish children.

\section{Methods}

We used the dataset of an anthropometric study which was performed in 2007 on children and adolescents living in Erzurum, a city of an altitude of 2000 meters in Turkey (9). A total of 1638 children and adolescents (871 males and 767 females) aged between 6 and 14 years were included in this study. The selection of the subjects was done after stratification according to their socioeconomic level and age, using the indicators of the Turkish Statistical Institute (10).

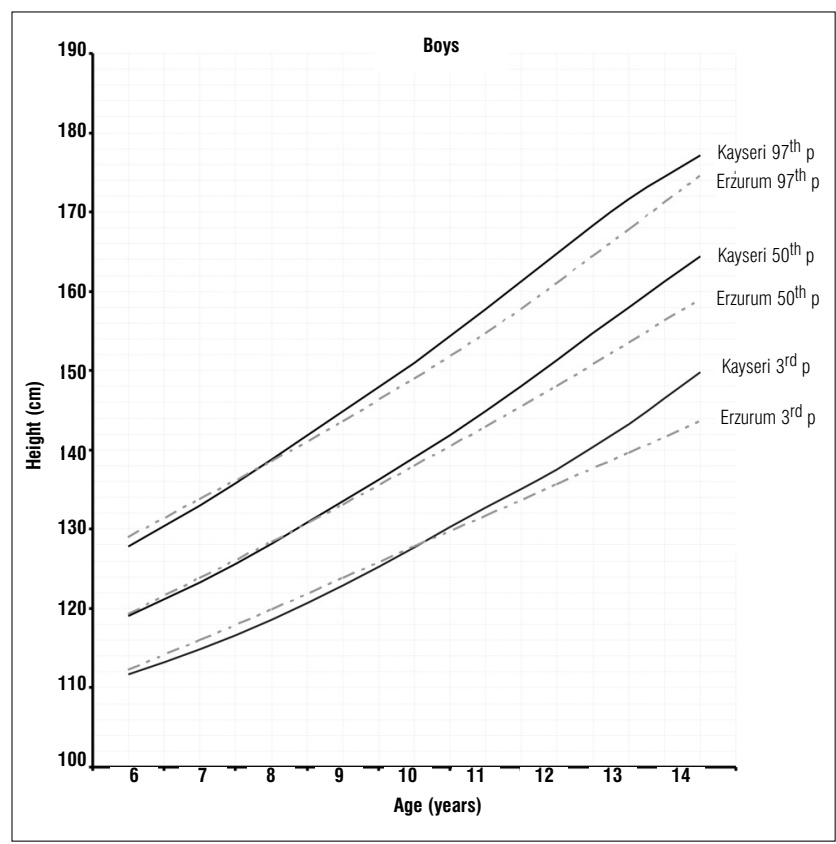

Figure 1a. $3^{\text {rd }}, 50^{\text {th }}$ and $97^{\text {th }}$ percentile values for height in Erzurum and Kayseri boys
Children who had chronic or systemic diseases that may interfere with growth were excluded from the study. The ethical approval for the study was obtained from the institutional review board of the Ataturk University in Erzurum.

The Harpenden stadiometer, a device calibrated to measure height with an accuracy of $0.05 \mathrm{~cm}$, was used for height measurements. All subjects were measured barefooted and lightly clothed. Weights were measured using a standard beam scale, sensitive to $0.1 \mathrm{~kg}$ (Tefal Ultraslim). Weight and height measurements were repeated twice, and the average value was recorded. All measurements were taken between 8 and 12 am to avoid errors due to within-day variability (11). BMl was calculated according to the standard equation [weight $(\mathrm{kg}) /$ height $(\mathrm{m})^{2}$ ].

The LMS method was used to fit smooth centile curves to the reference data $(12,13)$. With this method, percentiles based on age-specific Box-Cox power transformations that are used to normalize the data can be expressed. The final curves are produced by three smooth curves representing $L$ (Lambda; skewness), M (Mu; median) and S (Sigma; coefficient of variation). In this present study, the percentile values were estimated by the LMS Chart Maker Proversion 2.3 software program (The Institute of Child Health, London) and the centile curves $\left(3^{\text {rd }}, 5^{\text {th }}, 10^{\text {th }}, 15^{\text {th }}, 25^{\text {th }}, 50^{\text {th }}, 75^{\text {th }}\right.$, $85^{\text {th }}$, 90th, 95th and 97th) were constructed using Microsoft Office Excel ${ }^{\circledR}$ version 2003.

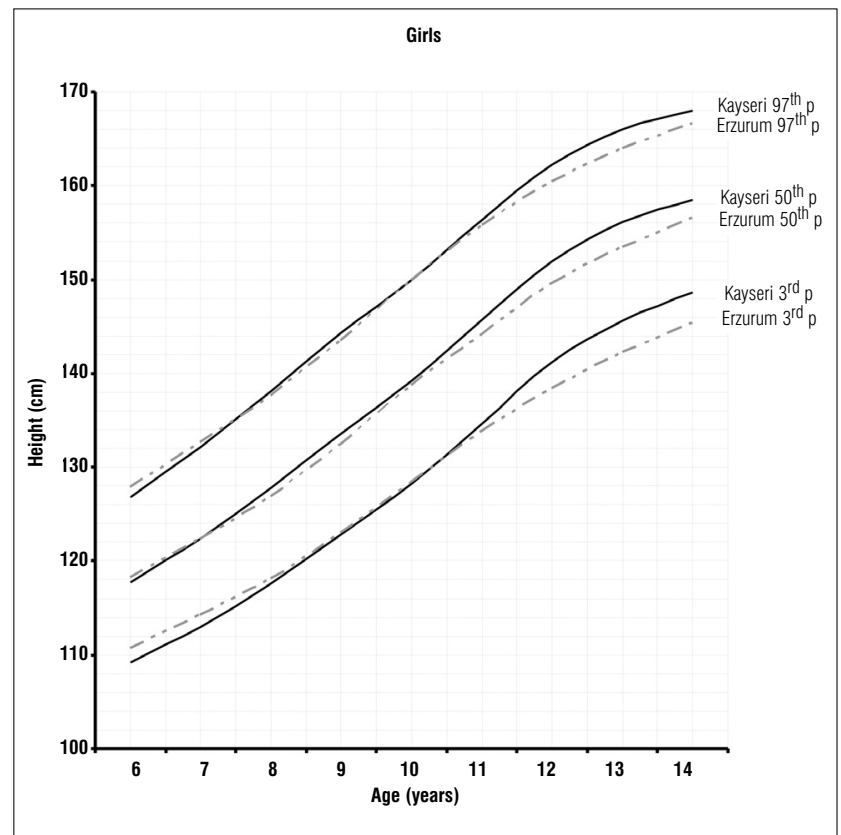

Figure 1 b. $3^{\text {rd }}, 50^{\text {th }}$ and $97^{\text {th }}$ percentile values for height in Erzurum and Kayseri girls 
We compared the $3^{\text {rd }}$, 50th , and $97^{\text {th }}$ percentile values for height, weight and BMl obtained in this study in Erzurum with the cross-sectional data from Turkish children residing in Kayseri (altitude of 1050 meters) (14). We also made a three-way comparison of $50^{\text {th }}$ percentile values for height, weight and BMl

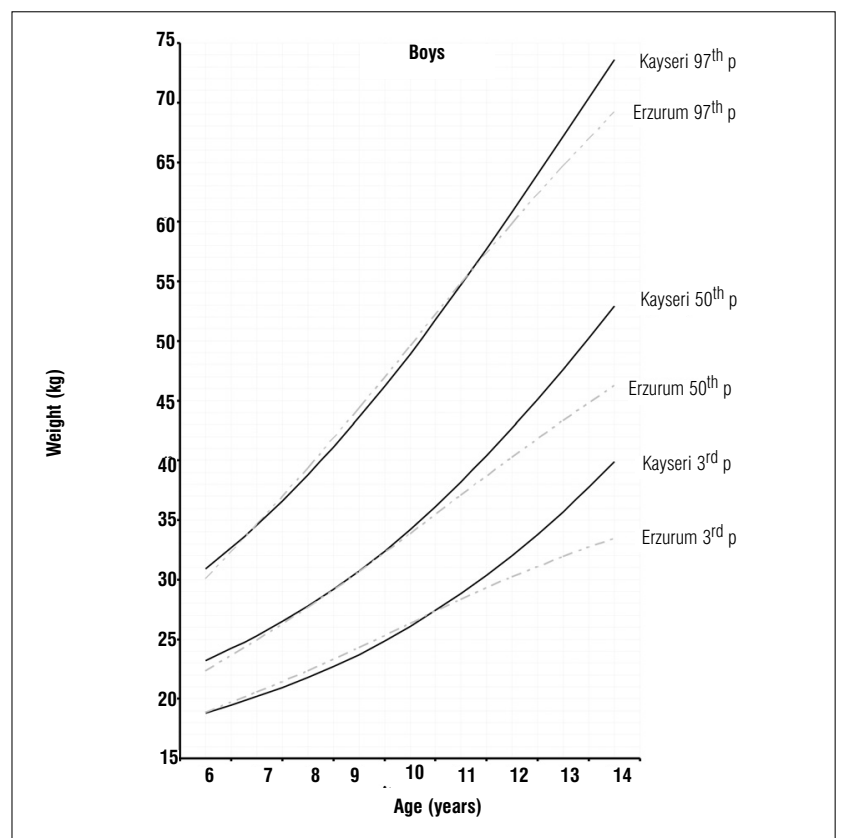

Figure 1c. $3^{\text {rd }}, 50^{\text {th }}$ and $97^{\text {th }}$ percentile values for weight in Erzurum and Kayseri boys

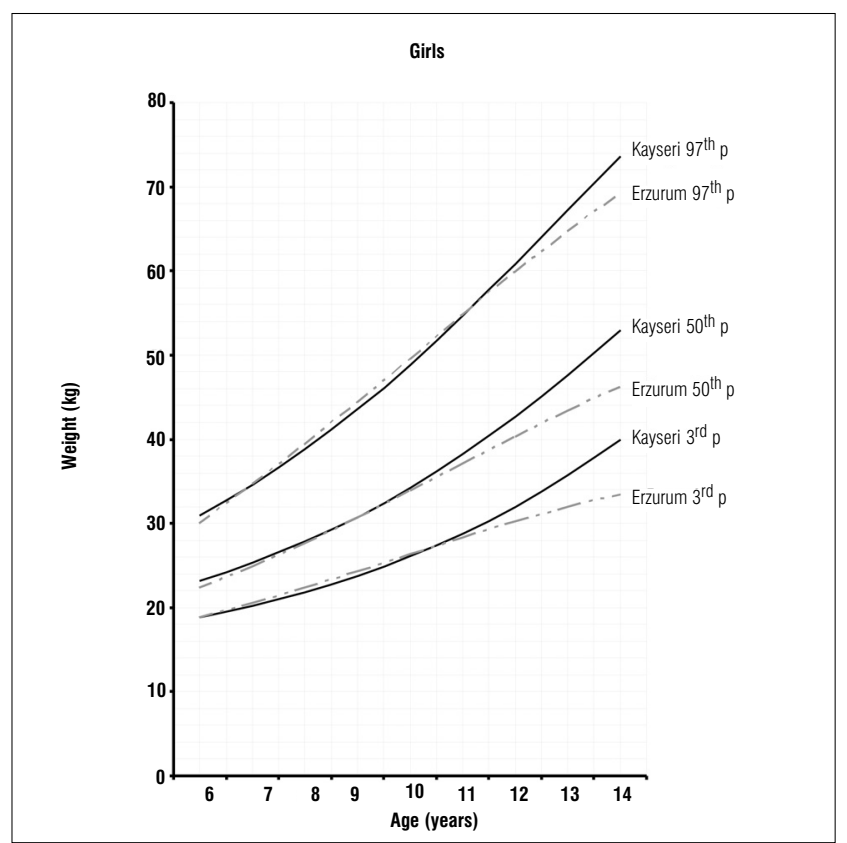

Figure 1d. $3^{\text {rd }}, 50^{\text {th }}$ and $97^{\text {th }}$ percentile values for weight in Erzurum and Kayseri girls obtained in this study (Erzurum; 2000 meters) with the data from children living in Istanbul (seaside level) and Kayseri (1050 meters) $(14,15)$. Descriptive statistics for each whole year (e.g., 6.00-6.99 y, etc.) within gender were calculated using SPSS version 13.0 (Illinois, Chicago, USA).

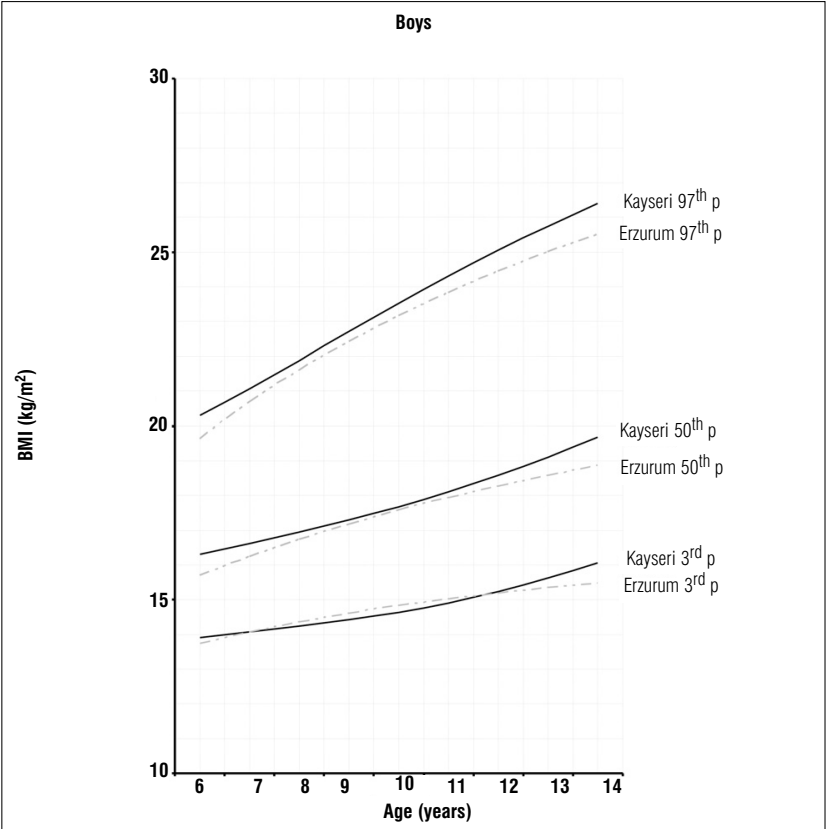

Figure 1e. $3^{\text {rd }}, 50^{\text {th }}$ and $97^{\text {th }}$ percentile values for weight in Erzurum and Kayseri boys

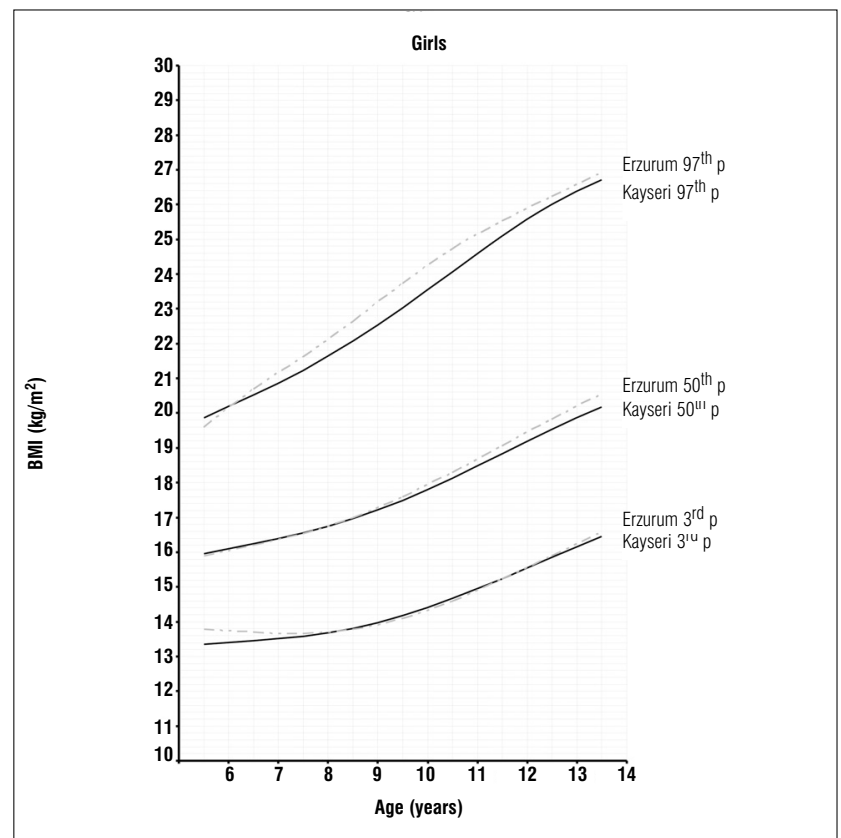

Figure 1f. $3^{\text {rd }}, 50^{\text {th }}$ and $97^{\text {th }}$ percentile values for BMl in Erzurum and Kayseri girls 


\section{Results}

Tables 1 to 3 present LMS values and $3^{\text {rd }}, 5^{\text {th }}, 10^{\text {th }}, 15^{\text {th }}$, $25^{\text {th }}, 50^{\text {th }}, 75^{\text {th }}, 85^{\text {th }}, 90^{\text {th }}, 95^{\text {th }}$ and $97^{\text {th }}$ percentile values for weight, height and BMl by age and gender in 6-14 years old children and adolescents living in Erzurum at an altitude of 2000

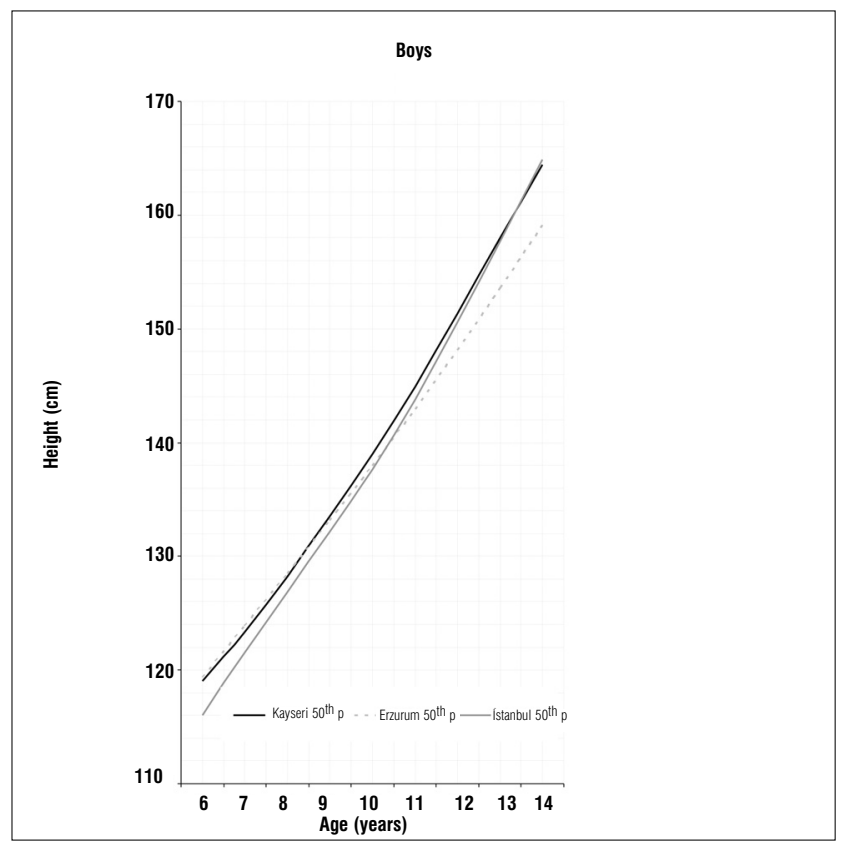

Figure 2a. 50th percentile values for height in Erzurum, Kayseri and Istanbul boys

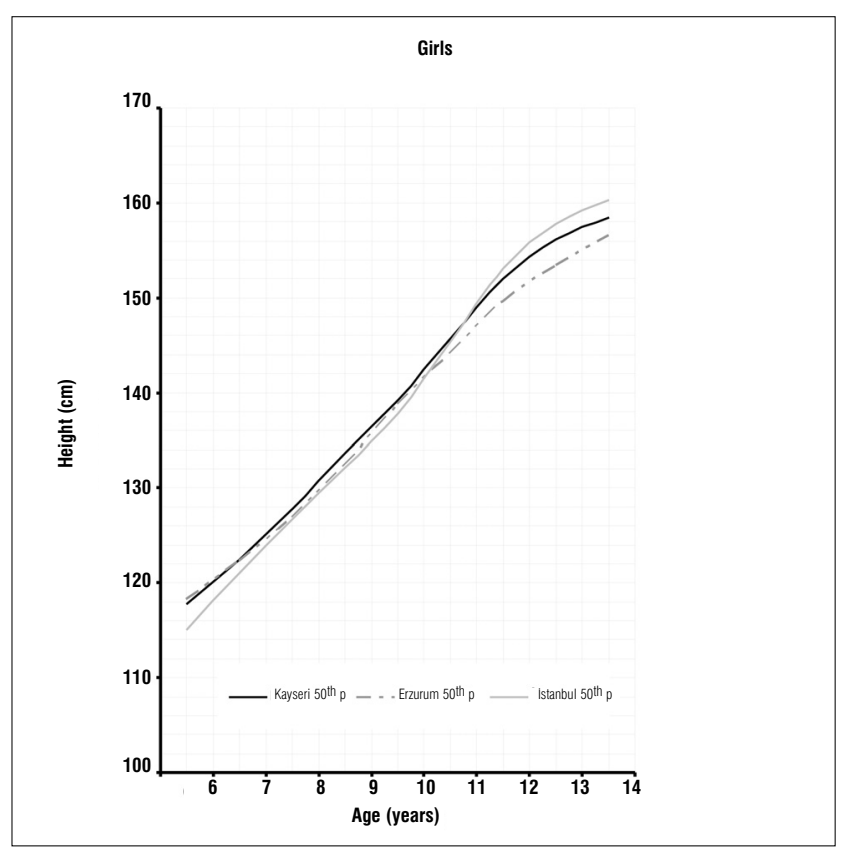

Figure $\mathbf{2 b}$. $50^{\text {th }}$ percentile values for height in Erzurum, Kayseri and Istanbul girls meters. Figures 1 a to $1 \mathrm{f}$ depict the $3^{\text {rd }}$, 50th and $97^{\text {th }}$ percentiles for height, weight and BMl in both genders in Erzurum and Kayseri subjects. Figures $1 \mathrm{a}$ to $2 \mathrm{f}$ compare $50^{\text {th }}$ percentile values in both genders in children from three cities of different altitudes (Erzurum - 2000 meters, Kayseri - 1050 meters, Istanbul seaside).

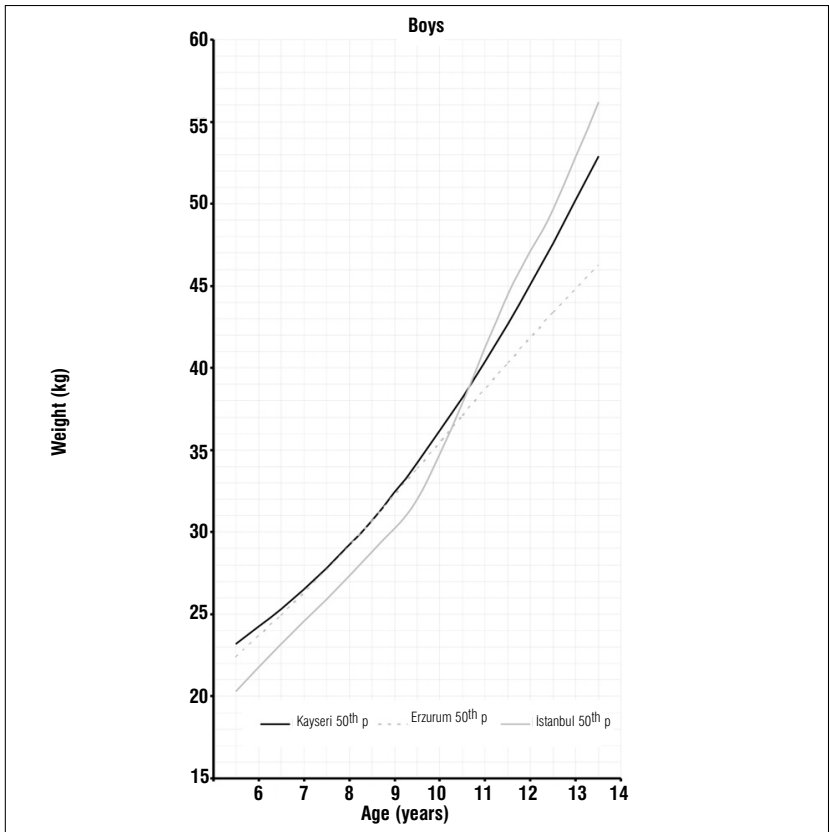

Figure 2c. 50th percentile values for weight in Erzurum, Kayseri and Istanbul boys

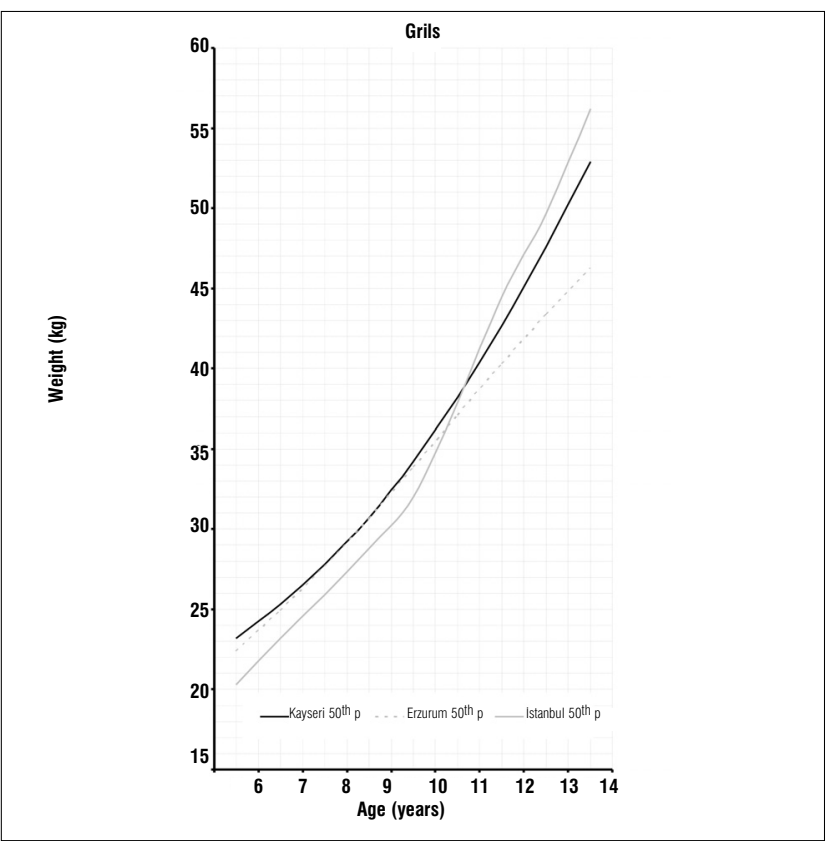

Figure 2d. 50th percentile values for weight in Erzurum, Kayseri and Istanbul girls 


\section{Discussion}

Hypobaric hypoxia due to high altitude leads to physiological adaptations in body functions and composition. These adaptation efforts may lead to physical alterations, pertaining to body fat, body weight, BMl and chest dimensions (16). These

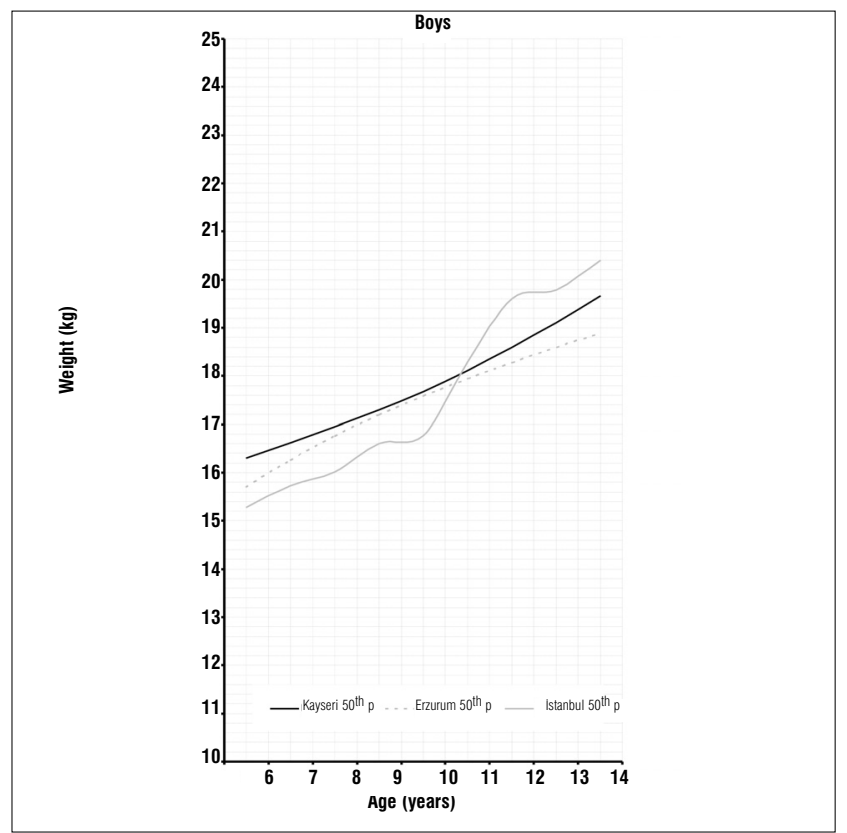

Figure 2e. 50th percentile values for BMl in Erzurum, Kayseri and Istanbul boys changes may be transient or permanent depending on time of exposure to altitude, level of altitude, speed of ascent and personal characteristics (5). In view of reports indicating that hypobaric hypoxia may cause alterations in growth even at moderate altitudes, we designed this preliminary study to compare the growth indicators of children living in a moderate-

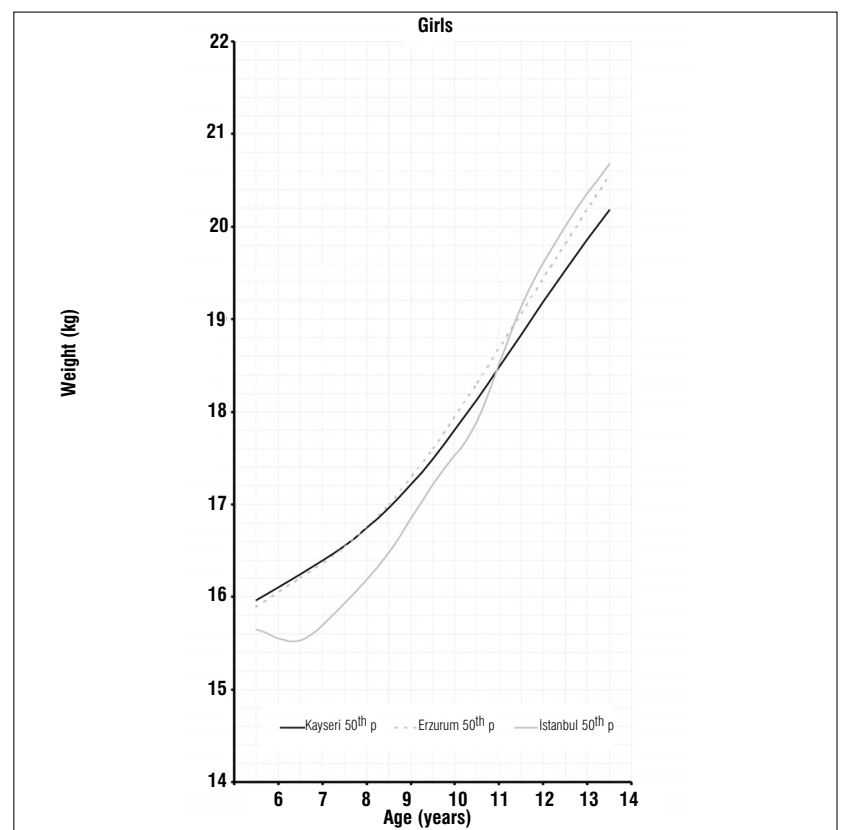

Figure 2f. 50 th percentile values for BMl in Erzurum, Kayseri and Istanbul girls

Table 1. LMS values and $3^{\text {rd }}, 5^{\text {th }}, 10^{\text {th }}, 15^{\text {th }}, 25^{\text {th }}, 50^{\text {th }}, 75^{\text {th }}, 85^{\text {th }}, 90^{\text {th }}, 95^{\text {th }}$ and $97^{\text {th }}$ percentiles for height in Erzurum boys and girls

\begin{tabular}{|c|c|c|c|c|c|c|c|c|c|c|c|c|c|c|}
\hline Age (years) & L & M & $S$ & 3 rd $p$ & $5^{\text {th }} \mathrm{p}$ & $10^{\text {th }} p$ & $\begin{array}{l}\text { Boys } \\
15^{\text {th }} p\end{array}$ & $25^{\text {th }} p$ & 50th $p$ & 75th $p$ & 85th $p$ & $90^{\text {th }} \mathrm{p}$ & 95th $p$ & $97^{\text {th }} p$ \\
\hline 6 & -3.563 & 119.3 & 0.036 & 112.3 & 113.0 & 114.3 & 115.2 & 116.6 & 119.3 & 122.4 & 124.2 & 125.5 & 127.6 & 129.0 \\
\hline 7 & -2.390 & 123.8 & 0.037 & 116.0 & 116.9 & 118.3 & 119.3 & 120.8 & 123.8 & 127.1 & 129.0 & 130.3 & 132.3 & 133.7 \\
\hline 8 & -1.424 & 128.4 & 0.038 & 119.9 & 120.9 & 122.4 & 123.5 & 125.2 & 128.4 & 131.8 & 133.8 & 135.1 & 137.2 & 138.6 \\
\hline 9 & -6.568 & 133.1 & 0.039 & 123.8 & 124.9 & 126.7 & 127.9 & 129.6 & 133.1 & 136.7 & 138.7 & 140.1 & 142.2 & 143.6 \\
\hline 10 & -0.745 & 138.0 & 0.041 & 127.8 & 129.0 & 130.9 & 132.3 & 134.2 & 138.0 & 141.8 & 143.9 & 145.4 & 147.6 & 149.0 \\
\hline 11 & 0.316 & 142.9 & 0.043 & 131.7 & 133.1 & 135.2 & 136.6 & 138.8 & 142.9 & 147.0 & 149.3 & 150.9 & 153.2 & 154.7 \\
\hline 12 & 0.552 & 148.1 & 0.046 & 135.6 & 137.1 & 139.5 & 141.1 & 143.5 & 148.1 & 152.6 & 155.1 & 156.8 & 159.3 & 161.0 \\
\hline 13 & 7.522 & 153.6 & 0.049 & 139.6 & 141.4 & 144.0 & 145.9 & 148.5 & 153.6 & 158.6 & 161.4 & 163.2 & 166.0 & 167.8 \\
\hline 14 & 1.004 & 159.1 & 0.052 & 143.5 & 145.5 & 148.5 & $\begin{array}{l}150.5 \\
\text { Girls }\end{array}$ & 153.5 & 159.1 & 164.6 & 167.6 & 169.7 & 172.7 & 174.6 \\
\hline 6 & -2.365 & 118.3 & 0.038 & 110.7 & 111.6 & 113.0 & 113.9 & 115.4 & 118.3 & 121.5 & 123.3 & 124.6 & 126.6 & 127.9 \\
\hline 7 & -2.166 & 122.4 & 0.039 & 114.2 & 115.2 & 116.6 & 117.7 & 119.2 & 122.4 & 125.8 & 127.7 & 129.1 & 131.2 & 132.6 \\
\hline 8 & -1.763 & 126.9 & 0.040 & 118.2 & 119.2 & 120.8 & 121.9 & 123.6 & 126.9 & 130.5 & 132.5 & 134.0 & 136.2 & 137.7 \\
\hline 9 & -1.000 & 132.5 & 0.041 & 123.0 & 124.1 & 125.9 & 127.1 & 128.9 & 132.5 & 136.2 & 138.4 & 139.8 & 142.0 & 143.5 \\
\hline 10 & -1.584 & 138.7 & 0.041 & 128.5 & 129.7 & 131.7 & 133.0 & 135.0 & 138.7 & 142.6 & 144.8 & 146.3 & 148.5 & 149.9 \\
\hline 11 & 6.463 & 144.2 & 0.404 & 133.9 & 135.2 & 137.3 & 138.7 & 140.8 & 144.2 & 148.7 & 150.8 & 152.3 & 154.5 & 155.9 \\
\hline 12 & 1.377 & 149.6 & 0.039 & 138.4 & 139.9 & 142.0 & 143.5 & 145.6 & 149.6 & 153.6 & 155.7 & 157.1 & 159.2 & 160.5 \\
\hline 13 & 1.928 & 153.5 & 0.038 & 142.3 & 143.7 & 145.9 & 147.4 & 149.6 & 153.5 & 157.3 & 159.7 & 160.7 & 162.7 & 164.0 \\
\hline 14 & 2.358 & 156.6 & 0.036 & 145.5 & 146.9 & 149.1 & 150.6 & 152.7 & 156.6 & 160.3 & 162.3 & 163.6 & 165.5 & 166.7 \\
\hline
\end{tabular}


altitude area with those of children of the same geographic region but living in areas of lower altitude (Kayseri, Turkey and Istanbul, Turkey). The lowest altitude where hypobaric hypoxia is reported to occur is 900 meters (17).
There are studies indicating that children living at altitudes of 3000 meters or over are lighter and shorter when compared with their counterparts who are born and brought up at lower altitudes $(18,19)$. However, reports also indicate that other than

\begin{tabular}{|c|c|c|c|c|c|c|c|c|c|c|c|c|c|c|}
\hline Age (years) & $\mathbf{L}$ & M & $S$ & $3^{\text {rd }} p$ & $5^{\text {th }} p$ & $10^{\text {th }} p$ & $\begin{array}{l}\text { Boys } \\
15^{\text {th }} p\end{array}$ & $25^{\text {th }} p$ & $50^{\text {th }} p$ & $75^{\text {th }} p$ & $85^{\text {th }} p$ & $90^{\text {th }} p$ & $95^{\text {th }} p$ & $97^{\text {th }} p$ \\
\hline 6 & -2.468 & 22.35 & 0.112 & 18.88 & 19.21 & 19.78 & 20.19 & 20.86 & 22.35 & 24.30 & 25.62 & 26.67 & 28.55 & 30.05 \\
\hline 7 & -2.131 & 24.92 & 0.126 & 20.58 & 21.00 & 21.70 & 22.21 & 23.05 & 24.92 & 27.37 & 29.04 & 30.37 & 32.75 & 34.64 \\
\hline 8 & -1.839 & 27.65 & 0.138 & 22.36 & 22.87 & 23.72 & 24.35 & 25.37 & 27.65 & 30.63 & 32.65 & 34.26 & 37.11 & 39.37 \\
\hline 9 & -1.581 & 30.65 & 0.149 & 24.31 & 24.92 & 25.94 & 26.70 & 27.92 & 30.65 & 34.20 & 36.59 & 38.47 & 41.79 & 44.38 \\
\hline 10 & -1.351 & 33.84 & 0.159 & 26.33 & 27.06 & 28.27 & 29.17 & 30.62 & 33.84 & 37.99 & 40.76 & 42.92 & 46.69 & 49.59 \\
\hline 11 & -1.142 & 37.09 & 0.167 & 28.34 & 29.19 & 30.61 & 31.65 & 33.35 & 37.09 & 41.85 & 45.00 & 47.44 & 51.62 & 54.80 \\
\hline 12 & -0.952 & 40.28 & 0.175 & 30.23 & 31.21 & 32.85 & 34.06 & 36.00 & 40.28 & 45.67 & 49.18 & 51.88 & 56.45 & 59.86 \\
\hline 13 & -0.777 & 43.35 & 0.183 & 31.96 & 33.08 & 34.95 & 36.32 & 38.53 & 43.35 & 49.35 & 53.21 & 56.15 & 61.06 & 64.68 \\
\hline 14 & -0.615 & 46.24 & 0.190 & 33.49 & 34.76 & 36.87 & $\begin{array}{l}38.41 \\
\text { Girls }\end{array}$ & 40.88 & 46.24 & 52.83 & 57.02 & 60.17 & 65.38 & 69.17 \\
\hline 6 & -1.726 & 22.48 & 1.403 & 18.08 & 18.51 & 19.22 & 19.74 & 20.59 & 22.48 & 24.93 & 26.58 & 27.88 & 30.17 & 31.97 \\
\hline 7 & -1.533 & 24.34 & 1.479 & 19.31 & 19.79 & 20.61 & 21.21 & 22.18 & 24.34 & 27.12 & 28.99 & 30.45 & 33.00 & 34.97 \\
\hline 8 & -1.314 & 26.44 & 1.562 & 20.62 & 21.19 & 22.14 & 22.83 & 23.96 & 26.44 & 29.62 & 31.72 & 33.36 & 36.18 & 38.33 \\
\hline 9 & -1.029 & 29.33 & 1.666 & 22.36 & 23.04 & 24.19 & 25.02 & 26.37 & 29.33 & 33.05 & 35.47 & 37.33 & 40.47 & 42.82 \\
\hline 10 & -7.223 & 33.32 & 0.176 & 24.75 & 25.61 & 27.03 & 28.06 & 29.73 & 33.32 & 37.73 & 40.54 & 42.65 & 46.14 & 48.69 \\
\hline 11 & -4.474 & 38.05 & 1.789 & 27.81 & 28.86 & 30.59 & 31.84 & 33.83 & 38.05 & 43.08 & 46.18 & 48.47 & 52.17 & 54.80 \\
\hline 12 & -2.467 & 42.74 & 1.704 & 31.39 & 32.59 & 34.55 & 35.95 & 38.16 & 42.74 & 48.02 & 51.20 & 53.49 & 57.14 & 59.68 \\
\hline 13 & -1.611 & 47.39 & 1.556 & 35.60 & 36.88 & 38.95 & 40.42 & 42.71 & 47.39 & 52.69 & 55.81 & 58.04 & 61.55 & 63.96 \\
\hline 14 & -1.653 & 52.14 & 1.396 & 40.33 & 41.62 & 43.71 & 45.20 & 47.49 & 52.14 & 57.33 & 60.36 & 62.52 & 65.89 & 68.19 \\
\hline
\end{tabular}

\begin{tabular}{|c|c|c|c|c|c|c|c|c|c|c|c|c|c|c|}
\hline Age (years) & $\mathbf{L}$ & M & $S$ & $3^{\text {rd }} p$ & $5^{\text {th }} p$ & $10^{\text {th }} p$ & $\begin{array}{c}\text { Boys } \\
15^{\text {th }} p\end{array}$ & $25^{\text {th }} p$ & $50^{\text {th }} \mathrm{p}$ & $75^{\text {th }} p$ & $85^{\text {th }} p$ & $90^{\text {th }} \mathrm{p}$ & $95^{\text {th }} p$ & $97^{\text {th }} p$ \\
\hline 6 & -2.973 & 15.7 & 0.087 & 13.7 & 13.9 & 14.3 & 14.5 & 14.9 & 15.7 & 16.7 & 17.4 & 18.0 & 18.9 & 19.6 \\
\hline 7 & -2.751 & 16.3 & 0.094 & 14.1 & 14.3 & 14.7 & 14.9 & 15.3 & 16.3 & 17.4 & 18.2 & 18.8 & 19.9 & 20.7 \\
\hline 8 & -2.556 & 16.7 & 0.100 & 14.4 & 14.6 & 15.0 & 15.3 & 15.7 & 16.7 & 18.0 & 18.9 & 19.5 & 20.7 & 21.6 \\
\hline 9 & -2.381 & 17.2 & 0.105 & 14.6 & 14.9 & 15.3 & 15.6 & 16.1 & 17.2 & 18.6 & 19.5 & 20.2 & 21.5 & 22.4 \\
\hline 10 & -2.223 & 17.6 & 0.110 & 14.8 & 15.1 & 15.6 & 15.9 & 16.4 & 17.6 & 19.1 & 20.0 & 20.8 & 22.1 & 23.2 \\
\hline 11 & -2.079 & 17.9 & 0.114 & 15.0 & 15.3 & 15.8 & 16.1 & 16.7 & 17.9 & 19.5 & 20.6 & 21.4 & 22.8 & 23.8 \\
\hline 12 & -1.946 & 18.3 & 0.118 & 15.2 & 15.5 & 16.0 & 16.4 & 17.0 & 18.3 & 19.9 & 21.0 & 21.9 & 23.3 & 24.5 \\
\hline 13 & -1.824 & 18.6 & 0.122 & 15.4 & 15.7 & 16.2 & 16.6 & 17.2 & 18.6 & 20.3 & 21.5 & 22.3 & 23.9 & 25.0 \\
\hline 14 & -1.709 & 18.9 & 0.125 & 15.5 & 15.8 & 16.4 & $\begin{array}{l}16.8 \\
\text { Girls }\end{array}$ & 17.4 & 18.9 & 20.7 & 21.9 & 22.8 & 24.3 & 25.5 \\
\hline 6 & -2.231 & 15.9 & 0.089 & 13.8 & 14.0 & 14.4 & 14.6 & 15.0 & 15.9 & 17.0 & 17.6 & 18.1 & 19.0 & 19.6 \\
\hline 7 & -1.859 & 16.2 & 0.105 & 13.7 & 14.0 & 14.4 & 14.7 & 15.2 & 16.2 & 17.5 & 18.3 & 18.9 & 19.9 & 20.7 \\
\hline 8 & -1.513 & 16.5 & 0.117 & 13.7 & 14.0 & 14.4 & 14.8 & 15.3 & 16.5 & 18.0 & 18.9 & 19.6 & 20.8 & 21.6 \\
\hline 9 & -1.276 & 17.0 & 0.128 & 13.8 & 14.1 & 14.6 & 15.0 & 15.7 & 17.0 & 18.6 & 19.6 & 20.4 & 21.7 & 22.6 \\
\hline 10 & -1.170 & 17.6 & 0.134 & 14.1 & 14.5 & 15.0 & 15.5 & 16.1 & 17.6 & 19.4 & 20.5 & 21.3 & 22.7 & 23.7 \\
\hline 11 & -1.100 & 18.3 & 0.136 & 14.6 & 15.0 & 15.6 & 16.0 & 16.8 & 18.3 & 20.2 & 21.3 & 22.2 & 23.7 & 24.7 \\
\hline 12 & -1.030 & 19.1 & 0.134 & 15.2 & 15.6 & 16.3 & 16.7 & 17.5 & 19.1 & 21.0 & 22.1 & 23.0 & 24.5 & 25.5 \\
\hline 13 & -0.981 & 19.8 & 0.131 & 15.9 & 16.3 & 17.0 & 17.5 & 18.2 & 19.8 & 21.7 & 22.9 & 23.8 & 25.2 & 26.2 \\
\hline 14 & -0.952 & 20.6 & 0.127 & 16.6 & 17.0 & 17.7 & 18.2 & 18.9 & 20.6 & 22.5 & 23.6 & 24.5 & 25.9 & 26.9 \\
\hline
\end{tabular}


high altitude and hypobaric hypoxia, adverse microclimate conditions (heat, humidity, wind levels) as well as individual characteristics may also cause poor growth performance in these children $(20,21)$.

In this preliminary study, based on the premise that alterations in growth and development may also occur in areas of moderate altitude, we produced age- and gender-specific percentiles for children and adolescents aged between 6 and 14 years and living in a moderate-altitude area (Erzurum) in Turkey.

We compared the $3^{\text {rd }}, 50^{\text {th }}$ and $97^{\text {th }}$ percentile values for height, weight and $\mathrm{BMl}$ of these children living at a moderately high altitude (2000 meters) with those of their counterparts living in a lower altitude (1050 meters) area and found that the values were noticeably lower in the higher altitude group in both genders, starting at ages $9-10$ years (Figures $1 \mathrm{a}$ to $1 \mathrm{f}$ ).

We also compared the $50^{\text {th }}$ percentile values obtained from these children living in an area of moderate altitude with those of children living at 1050 meters and at seaside level. Although there are differences in the design of these three studies, we believe that a comparison of 50th percentile values would be beneficial to a discussion on growth at different altitude levels (Figures 2a to 2f). The above-mentioned comparisons also showed no noticeable differences in growth at younger ages, but a decline in $50^{\text {th }}$ percentile values in children reared in the moderately high altitude area as compared to the other two groups, starting at ages 9-10 years.

The major limitations of our study may be the relatively small sample size and the lack of information on inter-observer and intra-observer differences.

In conclusion, the current study provides height, weight and BMl percentiles of Turkish boys and girls aged between 6 and 14 years living in a moderately high altitude area in Turkey. The results indicate that these children show a relatively stunted growth after ages 9-10 as compared to children living at lower altitudes in Turkey. These results point to the possibility of an altitude effect, but differences caused by socioeconomic and microclimate characteristics cannot be dismissed.

\section{References}

1. Wei C. Physiology of normal growth. Paediatr Child Health 2009;19:236-240

2. Mueller WH, Schull VN, Schull WJ, Soto P, Rothhammer F. A multinational Andean genetic and health program: growth and development in an hypoxic environment. Ann Hum Biol 1978;5:329-352.
3. Argnani L, Cogo A, Gualdi-Russo E. Growth and nutritional status of Tibetan children at high altitude. Coll Antropol 2008;32:807-812.

4. Roach RC, Hackett PH. Frontiers of hypoxia research: acute mountain sickness. J Exp Biol 2001;204:3161-3170.

5. Honigman B, Theis MK, Koziol-McLain J, Roach R, Yip R, Houston C, Moore LG, Pearce P. Acute mountain sickness in a general tourist population at moderate altitudes. Ann Intern Med 1993;118:587-92.

6. Theis MK, Honigman B, Yip R, McBride D, Houston CS, Moore LG. Acute mountain sickness in children at 2835 meters. Am J Dis Child 1993:147:143-145.

7. de Meer K, Bergman R, Kusner JS, Voorhoeve HW.Differences in physical growth of Aymara and Quechua children living at high altitude in Peru. Am J Phys Anthropol 1993:90:59-75.

8. Greksa LP, Spielvogel H, Caceres E.Effect of altitude on the physical growth of upper-class children of European ancestry. Ann Hum Biol 1985; 12:225-232.

9. Ülker Ismet. Dağlarımız. T.C. Kültür bakanlığı kütüphane ve yayımlar genel müdürlüğü Sanat Eserleri Dizisi 453, Ankara 2006:238.

10. http://mww.tuik.gov.tr/Start.do

11. Kaya MD, Hasiloglu AS., Bayramoglu M, Yesilyurt H, Ozok AF. A new approach to estimate anthropometric measurements by adaptive neuro-fuzzy inference systems. Int J Ind Ergon 2003;32:105-114.

12. Cole TJ, Green PJ. Smoothing reference centile curves: the LMS method and penalized likelihood. Stat Med 1992;11: 1305-1319.

13. Cole TJ. Fitting smoothed centile curves to reference data. JR Stat Soc 1988;151:385-418.

14. Hatipoglu N, Kurtoglu S, Ozturk A, Mazicioglu MM. The Weight and Height Percentiles in 6-18 Year Old Children in Kayseri and Comparison with Istanbul Data J Clin Res Ped Endo 2009;1:129-135.

15. Neyzi O, Andrzej F, Bundak R, Günóz H, Darendeliler $F$, Bafl F. Growth references for Turkish children aged 6 to 18 years. Acta Paediatr 2006;95:1635-1641.

16. Fiorri $F$, Facchini $F$, Ismagulv $O$, Ismaulova $A$, TarazonaSantos E, Pettener D. Lung volume, chest size and hematological variation in low-, medium-, and high altitude central asian populations. Am J Phys Anthropol 2000;113: 47-59.

17. Muza SR, Beidleman BA, Fulc CS, Altitude preexposure recommendatins for inducing acclimatization. High Altitude Medicine and Biology 2010;11:87-92.

18. Weitz CA, Garruto RM. Growth of Han migrants at high altitude in central Asia. Am J Hum Biol 2004;16:405-419.

19. Frisancho AR, Newman MT, Baker P. Differences in stature and cortical thickness among highland Quechua indian boys. Am J Clin Nutr 1970;23:382-385.

20. Shephard RJ. Immune changes induced by exercise in an adverse environment. Can J Physiol Pharmacol 1998;76:539-546.

21. Shephard RJ and Shek PN. Immune dysfunction as a factor in heat illness. Crit Rev Immunol 1999;19:285-302. 